\title{
INCIDENTS ASSOCIATED WITH GAS OPERATION
}

\section{J. SZER ${ }^{1}$, E. BLAZIK-BOROWA ${ }^{2}$}

\begin{abstract}
This article shows incidents associated with the use of gas as an energy carrier. It presents selected incidents which have occurred in Poland and around the world in recent decades. Based on this, consequences of gas and air mixture explosions were analysed as well. The article presents the main causes of gas incidents which have taken place, as per instances which are similar worldwide. Incidents associated with the use of gas are not frequent, but at the same time very tragic as they often lead to illness or even death. In Poland, in the last twenty years, construction area disasters caused by gas explosions account for only $5 \%$ of all which have occurred, but the number of fatalities resulting from these cases is approximately $14 \%$. The number of individuals injured reached $39 \%$ of all construction disaster victims. Considering all these facts, it is necessary to undertake wide preventive measures in order to increase safety in the use of gaseous fuels.
\end{abstract}

Keywords: construction disaster, gas explosion, risk, hazards in the construction industry, Poland, Europe, USA

\section{INTRODUCTION}

Natural gas is a fuel of natural origin, which satisfies the demand for approximately $20 \%$ of the world's energy. Deposits of natural gas are located deep within the earth's crust, alone or alongside deposits of oil or coal. Natural gas is a mixture of gaseous hydrocarbons (ethane, methane, propane), liquid hydrocarbons, and varying amounts of carbon dioxide, nitrogen, hydrogen, hydrogen sulphide, and noble gases (argon, helium). After extraction and purification, the gas is transported over long distances through high-pressure gas pipelines. Subsequently from high-

\footnotetext{
1 PhD., Eng., Łódź University of Technology, Faculty of Civil Engineering, Architecture and Environmental Engineering, Politechniki 6 str. 90-924 Łódź, Poland, e-mail: jacek.szer@p.lodz.pl

${ }^{2}$ Prof., PhD., Eng., Lublin University of Technology, Faculty of Civil Engineering and Architecture, Nadbystrzycka 40 str., 20-618 Lublin, Poland, e-mail: e.blazik@pollu.pl
} 
pressure pipelines, through pressure reducing stations, the gas is transported via medium- and lowpressure pipelines, and eventually to gas networks and installations in particular buildings. Natural gas also can be transported in the form of LNG. Fig.1 shows the statistics concerning these two forms of gas transport. As it can be seen, about $2 / 3$ of the world's gas volume is transported via pipe installations. Taking this into account and considering the fact that gas consumption all over the world grows (Fig. 2), an increase in global gas installations length is expected. This is closely related to operational problems leading to failures of pipelines and thereby to various dangerous situations (damage, fires, explosions, building disasters) referred to incidents in this article.

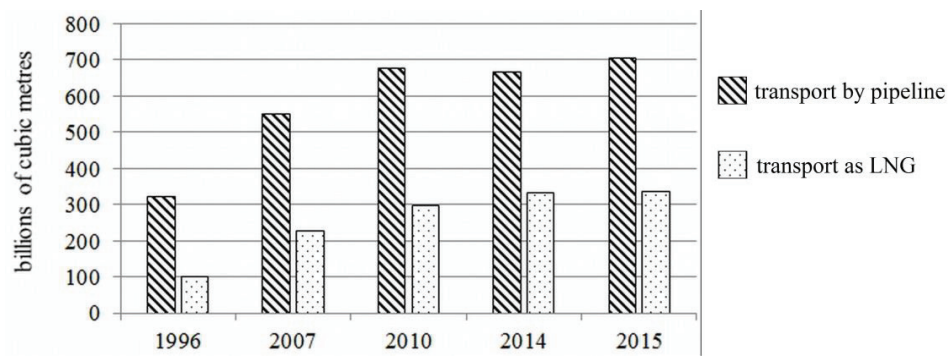

Fig. 1. Global gas distribution in years 1996-2015 based on data from [19].

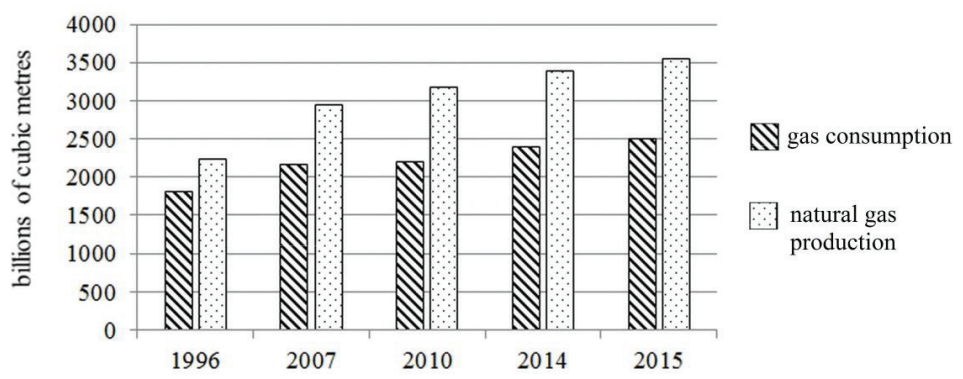

Fig. 2. Global gas consumption in years 1996-2015 based on data from [19].

Because of the hazards associated with gas installations and networks, institutions which collect data concerning gas installations and network systems as well as dangerous incidents related to their operation, are being established around the world. This institution in Poland is called the General Office of Building Control (GUNB), in Europe it's the European Gas Pipeline Incident Data Group (EGIG), and in the United States it's the Pipeline and Hazardous Materials Safety Administration (PHMSA). Using the databases of the mentioned institutions [7, 10, 18], and studies analysing the causes of pipe installation failures and gas explosions (comp. [2, 4, 5, 6, 8, 11, 13, 14, 15, 16, 20]), 
this article presents the scale of gas installation exploitation problems, indicating the main reasons for their failures. In order to demonstrate the importance of this problem, analysis of statistical data on failures and their consequences will be presented along reviews of building disasters involving gas installations. In contrast to other studies on this subject (see. $[2,4,5,6,7,8,10,11,13,14,15$, $16,19,20]$ ) which show analysis of single dangerous incidents in a single region of the world, the aim of this work is to compare problems related to gas networks worldwide. This paper presents the issue with a special focus set on different regions of the world, i.e. the USA, which is an association of semi-autonomic states, and Europe, a union of separate countries. Furthermore, this paper describes problems associated with failures of gas installations in one country, Poland (which is not covered by the program EGIG), comparing it to these two large areas.

\section{SELECT INCIDENTS CAUSED BY GAS EXPLOSIONS AROUND THE WORLD AND IN POLAND}

Natural gas has been used for hundreds of years, it is possible to find in existing literature information regarding the use of gas in 1785 in the United Kingdom for the lighting of homes and streets. Unfortunately, information about gas installation failures and gas explosions from this time period is rather inaccessible. Alongside the development of media and the increasing importance of human life, people started to pay attention to the problem of gas installation failure consequences. An overview of accidents related to gas installation failures can be found, among others, in publication [18]. In this article, a few select examples are recalled.

Historically, one of the most tragic recorded accidents related to gas explosion occurred in 1937 in a school in Texas. The cause of the explosion was improper design solutions in building construction and faulty gas pipe coupling. The result of the leaky gas tube connection was an accumulation of gas under the entire structure of the building, and as natural gas is invisible and odorless, the leak had not been detected in time. Around 300 teachers and students were killed as a result of this explosion. This incident had a direct impact on the adoption of legal solutions in Texas forcing gas suppliers to add fragrance to gas in order to facilitate its detection in cases of leakage and accumulation. Over time, this practice has been also adopted throughout the world.

Another tragic accident occurred in 1989 on the railway, close to Ufa, in the former Soviet Union. According to various sources, between 575 and 675 people died in this disaster, and over 800 were injured. Natural gas leaking from the pipeline, which ran in close proximity to the tracks of the Trans-Siberian railroad, exploded at a time when two trains carrying around 1300 people in total, 
were at the moment of passing each other. The direct cause of the explosion was a spark from the brake pads of both trains reducing their speeds simultaneously at a time when they also happened to be passing each other. The investigation showed that a few years earlier the pipeline had been damaged during excavation works, and then was improperly repaired. Unfortunately, that same incorrectly repaired damage led to the next pipeline leakage in 1989, causing the deadliest disaster ever in the history of the railway of the Soviet Union (and later Russia).

The next noted tragic incident took place in 1996 in Puerto Rico. In the commercial zone of Rio Pedras a gas explosion occurred, which killing 33 people and injuring 70. For several days beforehand, local employees had claimed to smell gas, however, the proper services inspecting the area hadn't been able to detect any irregularities. The inclusion of ventilation triggered an ignition, causing an explosion which destroyed the basement and ground floor of the commercial building. The investigation revealed that damage and leakage of an unmarked gas pipe which ran along a local narrow street was the reasons behind the explosion. A few years before the tragedy, new sewer pipes were placed underneath this region of road. The weight of the ground, local road traffic, and weather conditions led to a bending and damage of the gas pipe. Leaking gas had been moving around beneath the ground towards the basements of the trade zone, where it was then accumulating.

Obviously, gas installation incidents occur in Poland as well. One of the most tragic on record is the gas explosion which took place in 1976 in the city of Gdańsk. As a result of this incident, a 2-story residential building was completely destroyed. The building wasn't connected to the municipal gas network; the disaster occurred because of a gas leak from an underground pipeline running nearby. As in the previous incident, the escaped gas had accumulated in the basement of the building and exploded when one of the residents switched on the light. At the time of the explosion there were 28 people inside the building, 17 were killed and 11 injured.

Another accident with equally tragic consequences is the gas explosion in Warsaw's city center, at the intersection of Marszałkowska and Aleje Jerozolimskie streets which occurred in 1979. The explosion completely destroyed the Rotunda building, which, at the time, housed a branch of PKO bank. The cause of the explosion in this case was natural gas as well; it escaped from the damaged pipe through a duct of telecommunication installation, onto a building without its own gas installation. Pipeline damage probably occurred during conservation work, when a fixing screw of the gas valve was tightened too much. As a result of thermal contraction caused by low temperatures and ground movements caused by nearby aboveground transport pathways, the dome of the valve ruptured creating a $77 \mathrm{~cm}$-long gap. The snow cover prevented the escape of the gas to 
the surface, and low temperatures caused condensation of the added fragrance which was to warn people about possible leaks of gas. Eventually, the explosion was initiated by a shortage in the electrical system. This disaster resulted in 49 fatalities and 135 injuries.

In spite of the adoption of many legal regulations and developments of technology, incidents associated with use of gas still do occur. For example, in San Bruno, California (in 2010), gas leakage led to an explosion which resulted in the deaths of 8 people; 53 homes were destroyed and another 120 seriously damaged. In 2010 a New York gas explosion led to the destruction of 2 apartment buildings. As a result, 8 people were killed, 50 injured, and more than 100 families were left homeless. The cause was gas pipe damage due to ground scouring, which led to pipe deformation and leakage. In Poland, gas explosions caused by installation failures have occurred, among others, in 2011 in Kazimierz Dolny, in 2011 in Pustynia - a village located in Podkarpacie, in 2013 in Janków Przygodzki - a village located in Wielkopolska, and in 2014 in Katowice.

In all the described incidents, the explosions occurred due to gas network failure. Among the reasons were, for example, corrosion, road traffic, external interference, and atmospheric conditions. A more detailed analysis of gas pipeline failure causes will be presented in the next section together with a description of installation failure problem scales on a background of resources of this type of infrastructure.

\section{GAS INFRASTRUCTURE}

\subsection{GAS NETWORK RESOURCES}

As mentioned in the introduction, the gas network exploitation problem is related to the significant length of pipelines and increasing demands for energy produced from gas (Fig. 2). Table 1 shows a comparison of gas pipeline lengths in Poland [17], Europe [7], and the USA [9, 10]. For Poland and the USA, the entire length of the transmission and distribution pipeline systems is given, but in the case of Europe, it refers only to the length of pipelines with designed transmission pressures measuring above 15 bars, and operated by 17 gas providers including: Gas Networks Ireland (Ireland), DGC (Denmark), ENAGAS, SA (Spain), EUSTREAM (Slovakia), Fluxys (Belgium), Gasum (Finland), GRT Gaz (France), National Grid (UK), NET4GAS (Czech Republic), Gasunie (Netherlands / Germany), Gasconnect GmbH (Austria), Open Grid Europe (Germany), Ren Gasodutos SA (Portugal), Snam Rete Gas (Italia), Swedegas A.B. (Sweden), SWISSGAS (Switzerland), and TIGF (France). As one can see in Table 1, the entire length of the gas network is characterized by constant growth. A comparison of graphs also shows that this trend is similar for 
all analysed areas, showing that in the period from 1970 to 2000 the pipeline's length increase was more intense than at the present time. In Poland, over the last thirty years of the 20th century, the length of gas pipelines increased eight times, in Europe more than three times, but in the USA, by only about $50 \%$. In the last ten years, the differences in the percentage increases of pipeline lengths are smaller and in Poland account for $45 \%$, in Europe 30\%, and in the USA for $10 \%$. Finally, in 2013 in Poland, the total length of the gas network was $140000 \mathrm{~km}$, including $20000 \mathrm{~km}$ of transmission networks and $120000 \mathrm{~km}$ of distribution networks, in comparison, in the United States the length measured $479000 \mathrm{~km}$.

Table 1. Comparison of gas network lengths on the basis of data from $[7,10,17]$.

\begin{tabular}{|c|c|c|c|c|c|c|c|c|c|c|c|c|}
\hline \multicolumn{10}{|c|}{ The length of gas network * $1000 \mathrm{~km}$} \\
\hline Year & 1970 & 1980 & 1990 & 2000 & 2002 & 2004 & 2006 & 2008 & 2010 & 2011 & 2012 & 2013 \\
\hline Poland & 11.80 & 22.40 & 45.08 & 96.40 & 117.00 & 121.00 & 125.00 & 130.00 & 133.13 & 135.00 & 137.37 & 139.80 \\
\hline Europe & 31.00 & 65.00 & 87.00 & 110.00 & 112.00 & 122.00 & 125.00 & 131.00 & 135.00 & 142.00 & 142.00 & 143.00 \\
\hline USA & 847.00 & 968.30 & 1237.89 & 1349.76 & 1439.47 & 1445.30 & 1488.37 & 1513.18 & 1534.53 & 1544.01 & 1550.57 & 1557.81 \\
\hline
\end{tabular}

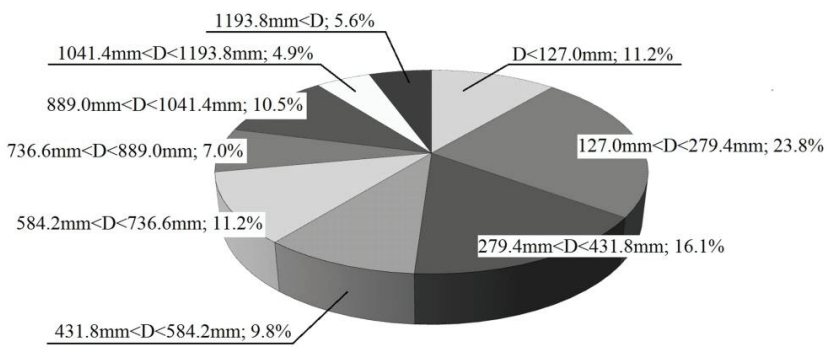

Fig. 3. The structure of the gas network with regards to pipe diameters in EGIG in Europe on the basis of [7].

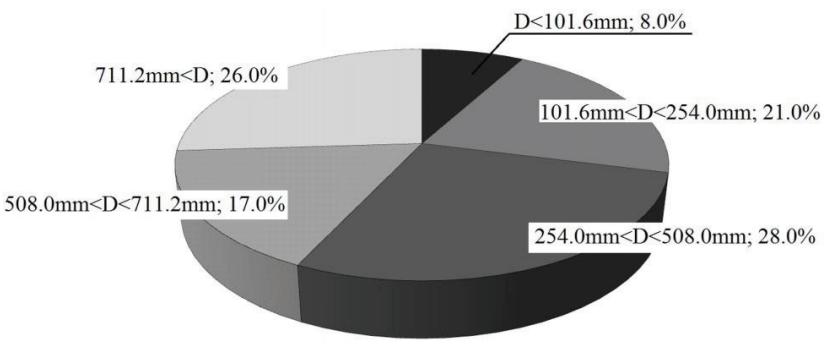

Fig. 4. The structure of the gas network with regards to pipe diameters in the USA on the basis of $[9,10]$. 
Fig. 3 and Fig. 4 also show the structure of gas networks in view of the diameter of outside pipes used in gas pipeline construction, respectively, in Europe and in the USA. Values given in figures relates to a set of diameters, therefore, a comparison will be made of the relevant groups of diameters with a certain approximation. Pipes with a diameter of less than $101.6 \mathrm{~mm}$ in Europe, and $127.0 \mathrm{~mm}$ in the USA account for about $20 \%$ of the total. Also, approximately $20 \%$ of all gas pipeline distribution systems have pipes with diameters ranging from $101.6 \mathrm{~mm}$ to $254.0 \mathrm{~mm}$ in Europe, and between $127 \mathrm{~mm}$ and $279.4 \mathrm{~mm}$ in the USA. However, in the USA, pipes with diameters of this range are most often used. In Europe, most of the pipes (28\%) have diameters of $254.0 \mathrm{~mm}$ to $508.0 \mathrm{~mm}$. The percentage of pipes with a diameter of more than $711.2 \mathrm{~mm}$ for Europe and $736.6 \mathrm{~mm}$ for US is similar, and respectively accounts for $26 \%$ and $28 \%$.

A very important role in maintenance of gas transport infrastructure plays its age. Fig. 5 shows the change of the age of structures. On the vertical axis is placed the percentage of total pipeline length of a certain age and on the horizontal axis an area which the data relates to and the year for which the juxtaposition of network length was performed. Gas networks in Europe are getting older, but still they are younger than those in the USA. In Europe as well as in the USA, about $25 \%$ of pipelines were built in the 1960s. However, in the USA, more than $50 \%$ of existing pipe length is over 40 years-old, whereas in Europe there are only about $35 \%$ of those kinds of networks. In publication (20), among others, it was indicated that causes like corrosion, failure during floods, pipes and pipe seam damage are closely connected to the 'aging' of pipelines. More information on failure causes will be indicated in the next point.

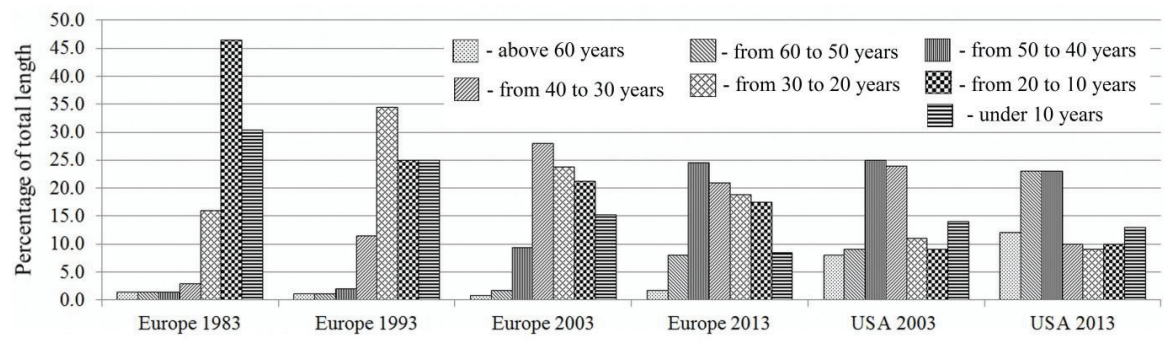

Fig. 5. The ageing structure of gas network in Europe and USA, age of the gas network.

\subsection{ANALYSIS OF CAUSES OF GAS NETWORK FAILURES}

Causes of gas network failures can be divided into following groups: external interferences, corrosion, construction-material defects, earth movement, and other environmental influences. 
External interferences include damage during excavations and other mechanical damage which results from external interferences not connected with the operation of gas pipelines, for example, from vandalism and fire. Occurrences of this kind of damage depend on pipe diameter, wall thickness, pipe laying depth, and, generally, pipeline location (underground, aboveground, submerged in water). Pipe corrosion can be divided into external and internal one. External corrosion depends on the environment where the pipes are located, whereas internal depends on the possibility of occurrences of localized excess pressure; on the geometry and possible inaccuracies in the execution of the pipeline and in the chemical composition of the gas itself (as well as its aggressiveness). Corrosion progresses with the age of the pipeline and depends on the type of the material which the pipes are made of and their wall thickness. Fig. 6 shows the percentage distribution of causes of installation failures in Europe and the USA. Failures of gas networks and installations in Poland are caused by the same reasons as in other countries in Europe and in the USA. However, due to a much smaller land area of the country and thus the smaller number of accidents, specification of these reasons even in statistical form will not accurately describe their reality. As one can see, external interferences and corrosion are the main causes of the failures in these parts of the world. However, corrosion, mainly of welded joints, also constitutes a big problem, including in China, where it inflicts severe economic losses [14, 20]. This corrosion was the cause (among others) of failure which took place in 2011 in the surroundings of a dam on the Yellow River and the Jinan-Qingdao express road. As a result of the explosion, a region of forest 100 square metres in area was destroyed and a few buildings were completely burnt down.

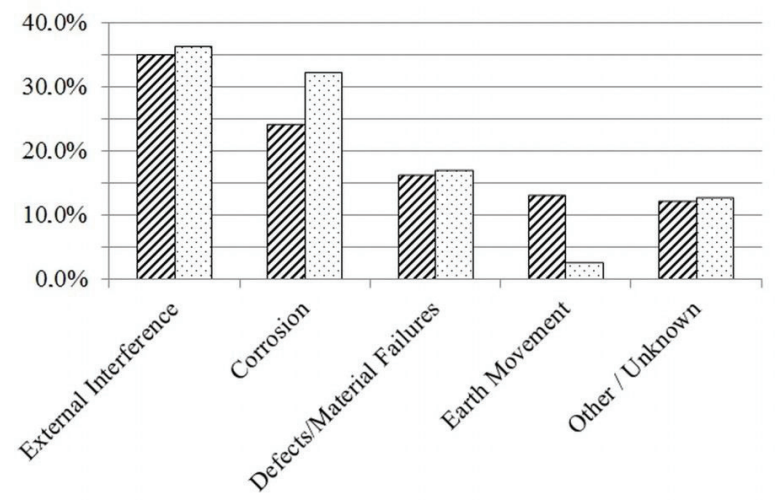

Fig. 6. The failure reasons of gas pipelines in Europe $\mathbb{N}_{\text {and in }}$ ine USA $\square$. 
The next factor group in terms of causing gas network failures is construction-material defects, including welded joint defects. The hazards for the occurrence of failures due to the mentioned causes increase alongside the age of the pipeline and depend on the geometry of the pipeline and the quality of its construction. For various reasons, a crack of the pipe or a cloud of the blend of explosive gas moving within the installation can come into existence inside. Upon encountering an obstacle, high pressure develops in the pipes leading to failure of an external installation, or in case of internal installation, to damage to the building. The scenarios and methodology for determining the probability of occurrence of these types of incidents were described in publications $[15,16]$.

In Europe, it has been stated that vibrations and ground movement triggered by seismic or/and paraseismic loads or/and floods, heavily contribute to the failures of gas pipelines. Ground movement and vibrations lead to damage to the installation, the consequences of which are explosions and fires. In publications [6, 11] an earthquake in Hyogo-Ken Nanbu, Japan in 1995 and its results were described; 234 different places were affected by fires caused by the leakage of gas stemming from that incident. The fire spread along a surface of 1 square $\mathrm{km}$. Another example of the failure of gas pipelines caused by earthquakes is in the city Chi-Chi. It took place in 1999 in Taiwan, as described in publication [5]. As a result of the damage to the gas pipeline and the gas leakage which followed, more than 100000 industrial installations and residential buildings were destroyed. Seismic loads also affect pipelines laid on the bottom of the sea. Damage to pipelines in these locations was inflicted, among others, during such earthquakes as [2]: the earthquake in Alaska in 1964, in San Francisco in 1971, in Guatemala in 1976, in Ecuador in 1987, in Kobe in 1995, and in Algeria in 2003. The last cause triggering vibrations and increasingly often causing damage to gas pipelines is the road traffic and the vibrations as its effect. Publication [4] describes gas explosions a few cities in Taiwan having different causes, with road traffic indicated the most often. Ground movement may also be caused by scouring during floods and/or as a result of a land subsidence (for example, in mining areas).

In the end it is also worth mentioning that damage caused by vibrations of low frequencies and significant displacements, which can be the result of various forms of flows of air and/or water around the pipes. Obviously, this kind of phenomena can occur only in cases of aboveground pipelines and pipelines laid on the seafloor. The issue of the interferences of flows to pipelines, with reference to one particular pipe, was described in publications $[2,8]$, and the issue of aerodynamic interference in the case of airflow around two pipes was described in publication [3]. Flow around one pipe of a circular cross-section generates vortexes, which with more-or-less permanent frequency detach from the surface of the pipe. Every detachment of a vortex triggers external forces 
perpendicular to the average direction of the flow. If the frequency of vortex detachment overlaps with the frequency of the vibrations of the pipeline, this may lead to a resonance and occurrence of vibrations of pipeline with significantly increased amplitudes. This phenomenon is called lock-in. If two pipes are laid side-by-side, there is flow leap-over, meaning flow either triggers vortexes on the external sides of the pipes, or the stream flows between pipes. Such phenomena most often take place when installations are mounted near a river but above the water's surface. The airflow (because of topography) is perfectly perpendicular to the pipes, and the speed of the flow increase in relation to the surroundings.

Due to the fact that failures of gas pipelines occur pretty often and cause many dangerous incidents, they are the subject of many publications $[2,4,5,6,8,11,13,14,15,16,20]$. On the other hand, gas network incidents have negative economic effects and, unfortunately, result in significant human casualties. A statistical analysis of the effects of these failures is described in the next subsection.

\subsection{GAS TRANSPORT INFRASTRUCTURES AND ASSOCIATED PROBLEMS}

Statistics show that, on the one hand, gas networks bring great economic benefits resulting in the development of this sector of the economy. On the other hand, the operation of external and internal gas networks is connected with numerous failures and human casualties. Within the last 20 years in Poland alone, 332 construction disasters caused by gas explosions were noted, 387 victims, including 57 people who died (referred to as fatalities in the paper), and 330 injuries. Per statistics carried out by the PHMSA within the last 20 years, 5664 incidents were registered, with 347 casualties and 1348 wounded.

According to statistics carried out since 1995 at the GUNB (see publications [18]), out of all 6366 construction disasters registered within the last twenty-year period, 332 were caused by gas explosions, accounting for $5 \%$ of the total. Fig. 7 shows a distribution of the number of the failures in Poland in years 1995-2013. Failures triggered by deliberate human activity are not taken into account with reference to construction disasters in Poland, which leaves a number of failures underestimated. However, it is possible to notice that, unfortunately, the number of accidents demonstrates increasing trends which mainly result from the growth of the length of the utilized pipelines, as presented in Fig. 10, where graphs show the number of accidents along the length of the installation per each $1000 \mathrm{~km}$. One may notice a slight increase of the number of disasters per 
each $1000 \mathrm{~km}$ of the installation when comparing to the beginnings of the 21 st century. In recent years, a stagnation in the number of failures is observable.

In Europe's EGIG group [7], during the period between 1970 and 2013, 1309 failures of gas pipeline networks occurred. Based on the graph (Fig. 8, Fig. 10) it is possible to observe the decrease in the number of incidents over the examined years, with a period of stagnation starting at the beginning of the 21 st century. Due to the lack of data regarding numbers of victims in the incidents, it is not possible to determine the ratio of the number of incidents to the number of injuries.

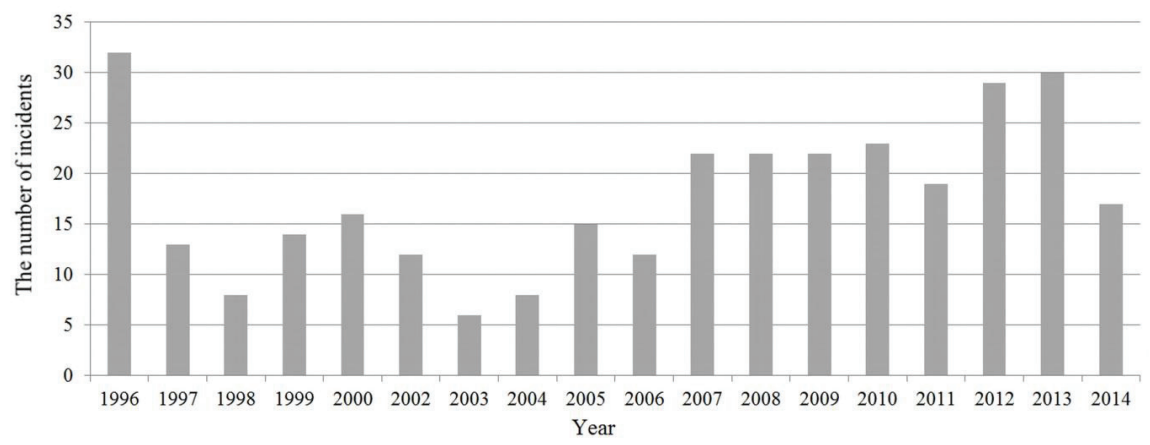

Fig. 7. The number of incidents in Poland caused by gas on the basis of [18].

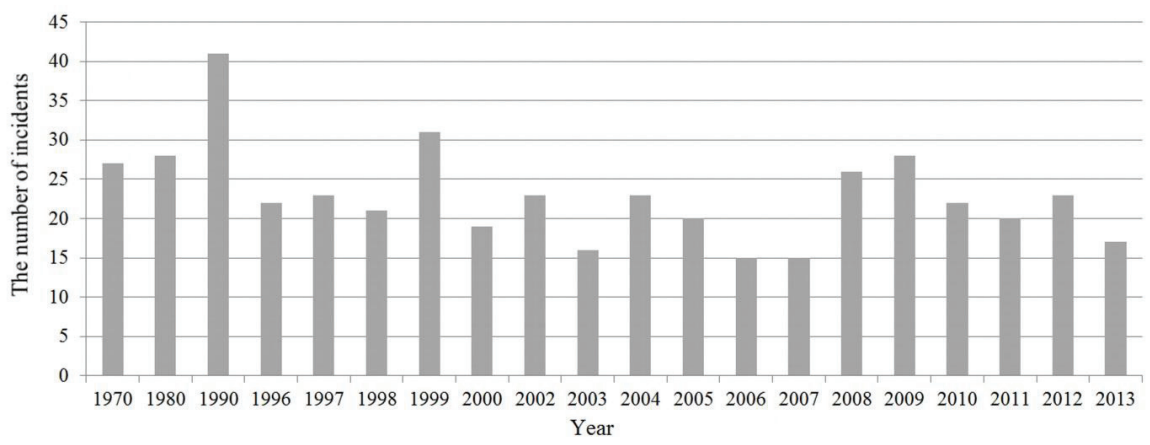

Fig. 8. The number of gas network incidents in Europe on the basis of [7]. 


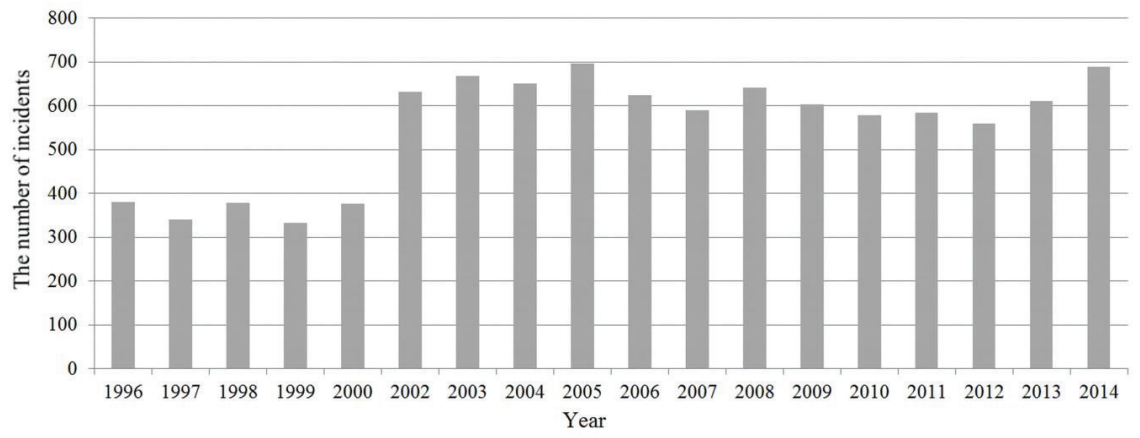

Fig. 9. The number of gas network incidents in the USA on the basis of [12].

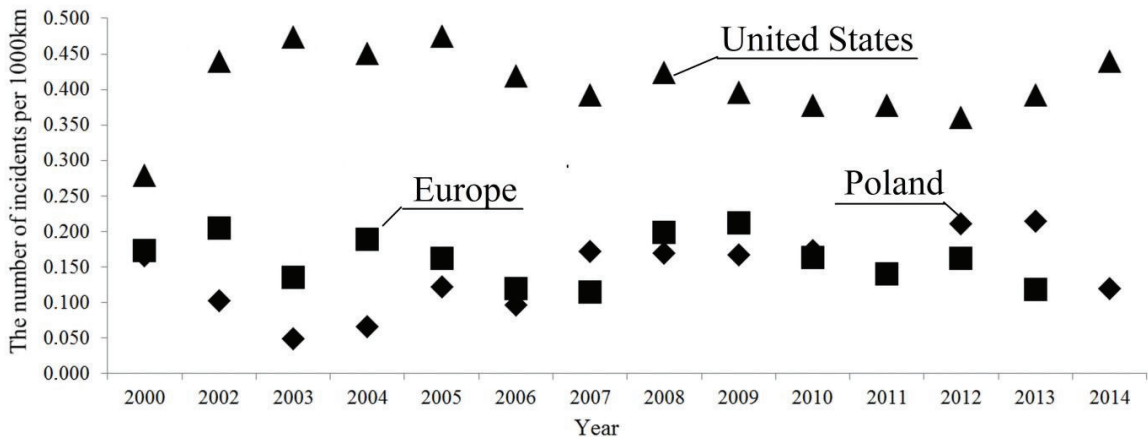

Fig. 10. The number of gas network incidents per $1000 \mathrm{~km}$.

Fig. 9 shows the number of gas network failures in the USA. In this region of the world, the number of gas network incidents was increasing and then reached a period of stagnation during the last ten years.

It is worth comparing the number of incidents per $1000 \mathrm{~km}$ in the mentioned areas; this kind of comparison for the last fifteen years is shown in Fig. 10. Over the last ten years, a stagnation in the number of incidents is noticeable in all of the analysed areas. In spite of many legal regulations, installation failures cannot be avoided due to aging. On the other hand, it is worth noting that the number of incidents in Poland is comparable to the entire region of Europe, however, the number of incidents in the United States is almost three times higher than in Europe. It can also correlate with the time of installation which, as shown in Fig. 5, is significantly earlier than installations of Europe. 


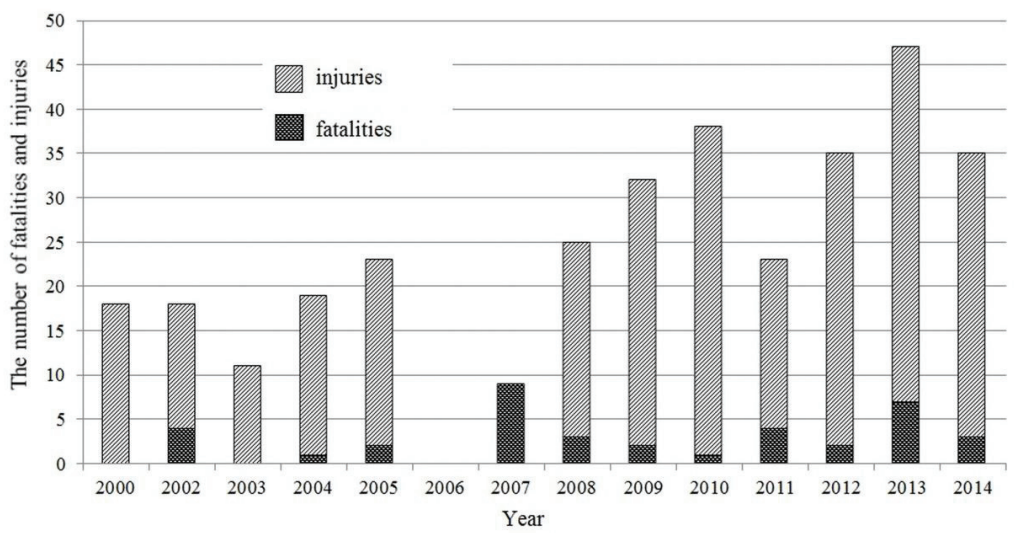

Fig. 11. The juxtaposition of the number of fatalities and injuries in Poland.

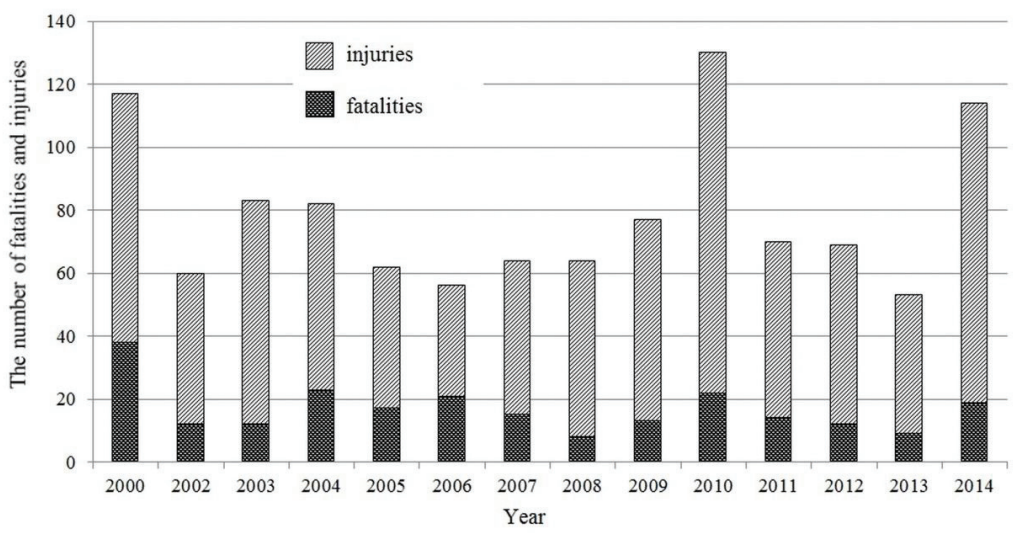

Fig. 12. The juxtaposition of the number of fatalities and injuries in the USA.

a)

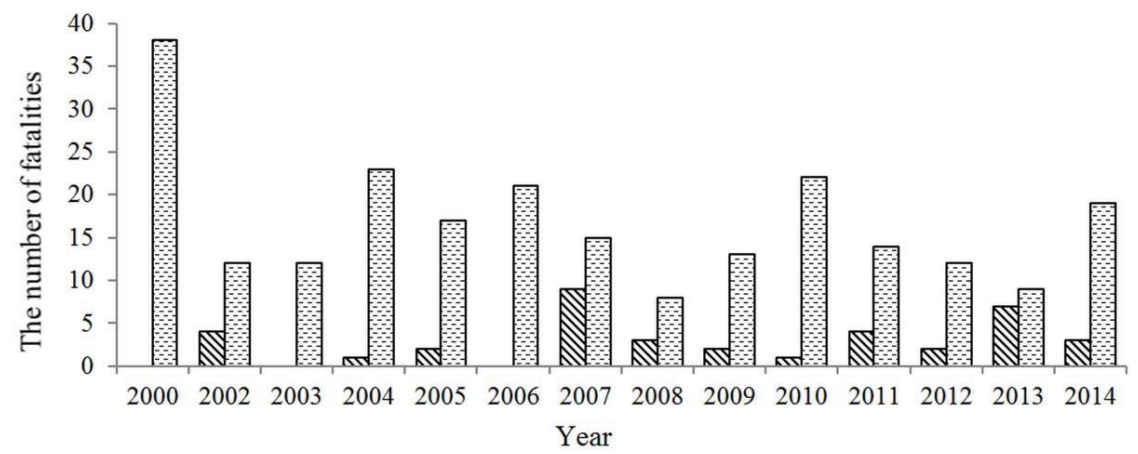




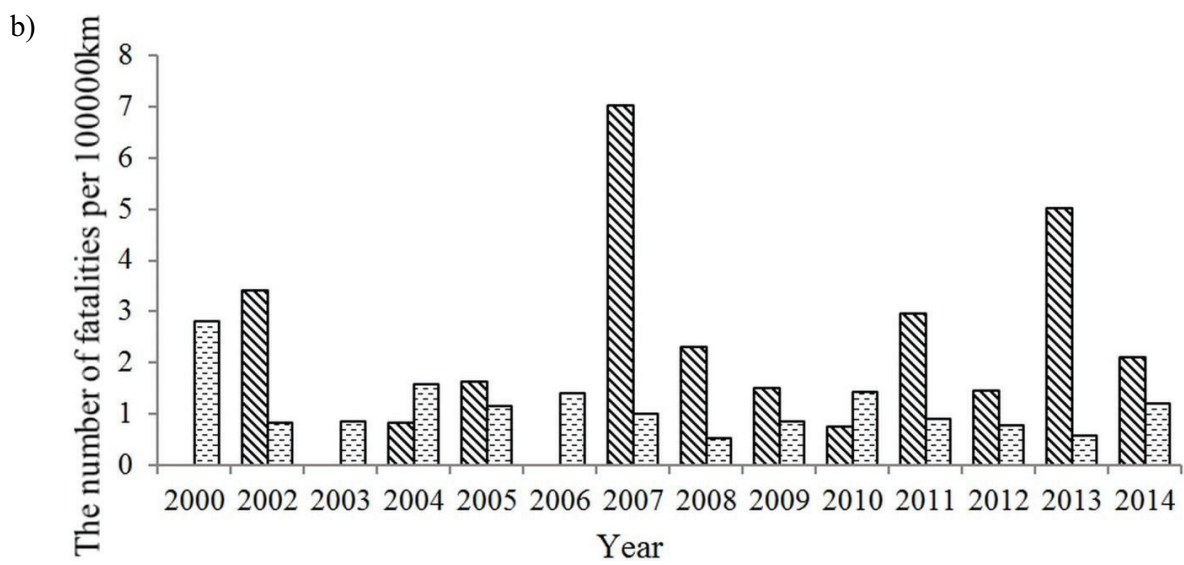

Fig. 13. The number of fatalities in Poland $\mathbb{N}$ and the USA $\mathbf{a}$ a) total number of fatalities, b) number of fatalities per 100 thousand $\mathrm{km}$.

As it was already mentioned, gas network incidents are connected with victims. Explosions, fires, and building collapses, which almost always have tragic outcomes for people, are quite often the effect of gas leakages. As stated in publication [18], in Poland the number of people who died in the years of 1995-2013 as a result of construction disasters caused by gas explosions represents $14 \%$ of all those killed as a result of construction disasters, and the number of injuries which took place in construction disasters represents as much as 39\%. Disasters caused by gas explosions constitute only $5 \%$ of all disasters, but proof of their destructive force and tragic effects is indicated by a disproportionately high percentage of injuries (39\%) and fatalities (14\%).

a)

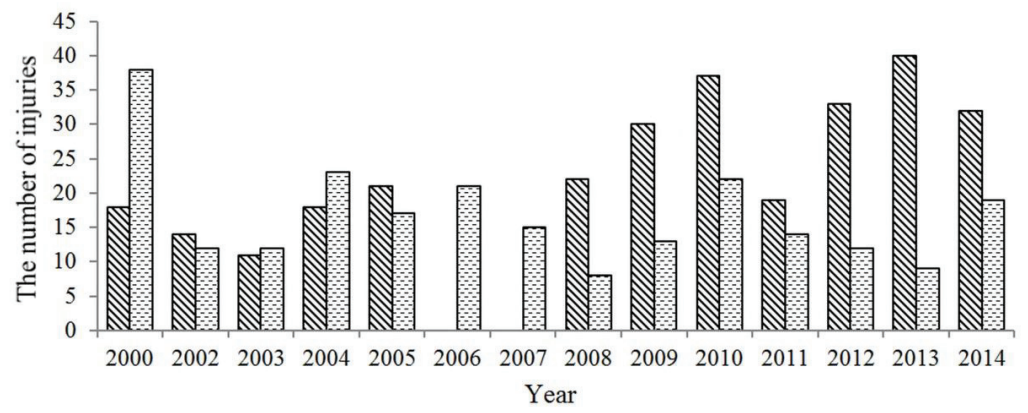


b)

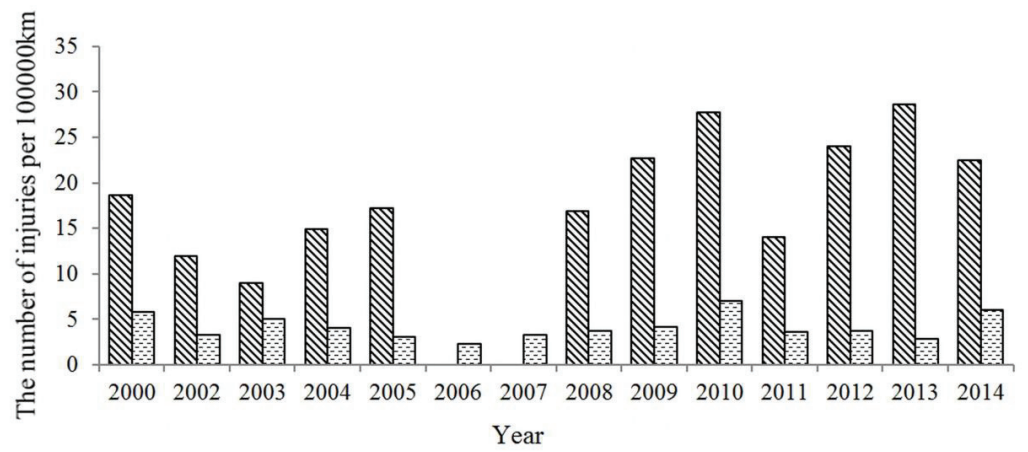

Fig. 14. The number of fatalities in Poland and the USA a) total number of injuries, b) number of injuries per $100000 \mathrm{~km}$.

Figs. 11-14 juxtapose the data of the numbers of fatalities and injuries in incidents which have occurred as a result of the failures of gas networks in Poland and in the USA. Statistics concerning Poland have an uneven distribution; the number of victims in relation to the number of incidents is high, which shows that at a smaller number of incidents, every incident with many victims distorts the comparability of data from individual years, though it is possible to notice in Fig. 11 that the number of victims in Poland is rising. The number of victims in the USA (Fig. 12) tends to decrease, but incidents with a large number of victims still happen, as is seen in the years of 2010 and 2014. There is also a greater percentage of fatalities among all the victims in the USA. Obviously, it is also noticeable that the total number of fatalities in the USA is larger than in Poland. However, when we refer to the length of the installation, unfortunately the situation in Poland looks more negative. The number of injuries is similar, but the number of injuries per 100 $000 \mathrm{~km}$ in Poland is much higher than in the USA.

Evidently, a larger number of victims per each $100000 \mathrm{~km}$ length of gas networks exists in Poland, simultaneously with a much greater number of gas network incidents per $1000 \mathrm{~km}$; this may be explained by population density. According to the GUS [17], Poland in 2014 had a population density of 38.5 inhabitants per $\mathrm{km}^{2}$, and North America had half that with only 19 per $\mathrm{km}^{2}$. In other words, the length of transmission lines is associated with long distances between population centres, and because of that the average number of victims is lower than in Poland. 


\section{CONCLuSiOnS}

On the basis of the presented analysis and statistics, it is possible to notice that the same problems of the failures of gas pipelines concern the entire world. Phenomena, such as corrosion and wear of elements of infrastructure resulting from "aging" of gas network resources, have a huge impact on the number of failures. The next group of causes results from negative environmental influences during earthquakes and floods. Also, loads of gas pipelines resulting from the development of the surrounding civilization are of major importance, and these are, for example, damage to gas pipelines caused during excavations works, para-seismic vibrations, disturbances by road traffic, and fires. Causes described in this article appear in each region of the world. Differences appear in their percentage distributions, which are connected with environmental conditions, the state of industry growth, and the general culture of safety.

In Poland, the increasing tendency can be seen in the scope of the number of incidents and victims. It is associated with the increase of gas network lengths. In accordance with analysis of the numbers of accidents and victims per $1000 \mathrm{~km}$ during ten last years, the number of dangerous incidents in gas network resources per $1000 \mathrm{~km}$ is fixed both in Poland and Europe, as well as in the USA. Increasing lengths of the network, increases in energy demand, and "aging" of gas network resources may lead to an increase in the number of failures, which can be avoided only by its proper operation and legal provisions, and notably through constant monitoring and adequate maintance.

Aknowledgements. This work was financially supported by the statutory budget funds of Faculty of Civil Engineering and Architecture in Lublin University of Technology and Faculty of Civil Engineering, Architecture and Environmental Engineering in Łódź University of Technology. 


\section{REFERENCES}

1. I. Albrycht, "The analysis of gas infrastructure in Poland with regarts to the perspective of future energy challenges and the development of the unconventional gas", Kościuszko Instytute, 2013.

2. Qiang Bai and Yong Bai, "Subsea Pipeline Design, Analysis and Installation", Elsevier Inc., http://dx.doi.org/10.1016/B978-0-12-386888-6.00018-3, 2014.

3. E. Błazik-Borowa, A. Flaga, "Numerical Analysis of Interference Galloping of Two Identical Circular Cylinders", Wind\&Structures 1(3): 243-253, 1998.

4. Chun-Hung Chen, Yeong-Nain Sheen, Her-YungWang, "Case analysis of catastrophic underground pipeline gas explosion in Taiwan", Engineering Failure Analysis 65: 39-47., 2016.

5. W.W. Chen, B.J. Shih, C.W. Wu, Y.C. Chen, "Natural gas pipeline system damages in the Ji-Ji earthquake (The City of Nantou)", Proc of the 6th Int.Conf. on Seismic Zonation, 2000.

6. EQE summary report. The January 17. 1995 Kobe earthquake. EQE International, 1995.

7. Gas Pipeline Incidents, "9th Report of the European Gas Pipeline Incident Data Group" (period 1970-2013), 2015.

8. J.D. Hart, R. Saure, R.G. Wyche, G.R. Dennls, "Mitigation of Wind Induced Vibration of Arctic Pipeline Systems", Proc. of the $11^{\text {th }}$ Int. Conf. on Offshore Mechanics and Arstlc Engineering, Book No. H0746A 169-180, 1992.

9. J.F. Kiefner, M.J. Rosenfeld, "The Role of Pipeline Age in Pipeline Safety”, INGAA Foundation Final Report NO. 2012.04, 2012

10. Chio Lam, Wenxing Zhou, "Statistical analyses of incidents on onshore gas transmission pipelines based on PHMSA database", International Journal of Pressure Vessels and Piping 145: 29-40, 2016.

11. Do Hyung Lee, Byeong Hwa Kim, Hacksoo Lee, Jung Sik Kong, "Seismic behavior of a buried gas pipeline under earthquake excitations", Engineering Structures 31: 1011-1023, 2009.

12. Ed.W.H. Moore, R. Duych, X.N. Long, H. Xiaoli, T. Lei, Z. Jie, S. Beningo, M. Chambers, C. Ford, K. Notis, M. Liu, "National Transportation Statistics", 2016.

13. A.H. Mousselli, "Offshore Pipeline Design", Analysis and Methods, PennWell Books, 1981.

14. Qiao Qiao, Guangxu Cheng, WeiWu, Yun Li, Hui Huang, ZefengWei, "Failure analysis of corrosion at an inhomogeneous welded joint in a natural gas gathering pipeline considering the combined action of multiple factors”, Engineering Failure Analysis 64: 126-143, 2016.

15. P. Russo, F. Parisi, N. Augenti, G. Russo, "Derivation of Risk Areas Associated with High-Pressure NaturalGas Pipelines Explosions Including Effects on Structural Components", Chemical Eng. Transactions 36: DOI: 10.3303/CET1436049, 2014.

16. P. Russo, F. Parisi, "Risk-targeted safety distance of reinforced concrete buildings from natural-gas transmission pipelines”, Reliability Engineering and System Safety 148: 57-66, 2016.

17. Statistical yearbook of the regions in Poland.

18. J. Szer, P. Jagielski, "Overview of construction disasters caused by gas explosion", Materiały budowlane 528: (8), 150-152, 2016.

19. D.A. Wood, "Competition is driving significant change in natural gas LNG and pipeline export markets", Journal of Natural Gas Science and Engineering, http://dx.doi.org/10.1016/j.jngse.2016.06.042, 2016

20. Yafan Zhao, Mingda Song, "Failure analysis of a natural gas pipeline", Engineering Failure Analysis 63: 61-71, 2016. 


\section{LIST OF FIGURES AND TABLES:}

Fig. 1. Global gas distribution in years 1996-2015 based on data from [19].

Rys. 1. Dystrybucja gazu na świecie w latach 1996-2015 na podstawie [19].

Fig. 2. Global gas consumption in years 1996-2015 based on data from [19].

Rys. 2. Konsumpcja gazu na świecie w latach 1996-2015 na podstawie [19]

Fig. 3. The structure of the gas network with regards to pipe diameters in EGIG in Europe on the basis of [7].

Rys. 3. Struktura sieci gazowych ze względu na średnicę rur w grupie w Europie na podstawie EGIG [7].

Fig. 4. The structure of the gas network with regards to pipe diameters in the USA on the basis of $[9,10]$.

Rys. 4. Struktura sieci gazowych ze względu na średnicę rur w Stanach Zjednoczonych na podstawie $[9,10]$.

Fig. 5. The ageing structure of gas network in Europe and USA, age of the gas network.

Rys. 5. Zmiana struktury wiekowej sieci gazowych w Europie i USA.

Fig. 6. The failure reasons of gas pipelines in Europe $\mathbb{\mathbb { N }}$ and in the USA

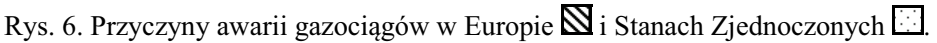

Fig. 7. The number of incidents in Poland caused by gas on the basis of [18].

Rys. 7. Liczba incydentów w Polsce z udziałem sieci gazowych na podstawie [18].

Fig. 8. The number of gas network incidents in Europe on basis of [7].

Rys. 8. Liczba incydentów w Europie z udziałem sieci gazowych grupy EGIG na podstawie [7].

Fig. 9. The number of gas network incidents in the USA on basis of [12].

Rys. 9. Liczba incydentów w USA z udziałem sieci gazowych na podstawie [12].

Fig. 10. The number of gas network incidents per $1000 \mathrm{~km}$.

Rys. 10. Liczba incydentów na $1000 \mathrm{~km}$.

Fig. 11. The juxtaposition of the number of fatalities and injuries in Poland.

Rys. 12. Zestawienie liczby ofiar śmiertelnych i liczby rannych w Polsce.

Fig. 12. The juxtaposition of the number of fatalities and injuries in the USA.

Rys. 13. Zestawienie liczby ofiar śmiertelnych i liczby rannych w USA.

Fig. 13. The number of fatalities in Poland $\mathbb{\mathbb { N }}$ and the USA $\mathbf{0}$ a) total number of fatalities, b) number of fatalities per 100 thousand $\mathrm{km}$.

Rys.13. Liczba ofiar śmiertelnych w Polsce i USA $\mathbf{Q}$, a) całkowita liczba ofiar, b) liczba ofiar na 100 tys. $\mathrm{km}$.

Fig. 14. The number of fatalities in Poland $\mathbb{N}$ and the USA a) total number of injuries, b) number of injuries per $100000 \mathrm{~km}$.

Rys.14. Liczba osób rannych w Polsce $\mathbb{N}$ i USA a) całkowita liczba osób rannych, b) liczba osób rannych na 100 tys. $\mathrm{km}$.

Tab. 1. Comparison of gas network lengths on the basis of data from [7, 10, 17].

Tab. 1. Porównanie długości sieci gazowych na podstawie [7, 10, 17]. 


\section{ZDARZENIA ZWIAZZANE ZE STOSOWANIEM GAZU}

Keywords: katastrofy budowlane, wybuch gazu, ryzyko, zagrożenia w budownictwie, Poland, Europe, USA

\section{STRESZCZENIE:}

Gaz ziemny jest to paliwo pochodzenia naturalnego, które zaspokaja zapotrzebowanie na ok. 20\% energii na świecie. Pokłady gazu ziemnego występują w skorupie ziemskiej samodzielnie lub towarzyszą złożom ropy naftowej lub węgla kamiennego. Gaz ziemny stanowi mieszankę węglowodorów gazowych (etan, metan, propan), węglowodorów ciekłych oraz pewnych ilości dwutlenku węgla, azotu, wodoru, siarkowodoru, gazów szlachetnych (argon, hel). Po wydobyciu i oczyszczeniu gaz transportowany jest na dalekie odległości gazociągami wysokociśnieniowymi. Gaz ziemny może być również transportowany w formie gazu skroplonego. Na świecie około $2 / 3$ objętości gazu jest transportowana za pomocą instalacji rurowych. Biorąc to pod uwagę oraz fakt wzrostu konsumpcji gazu na świecie należy oczekiwać wzrostu długości instalacji gazowych na świecie, a co z tym jest ściśle związane - problemów eksploatacyjnych kończących się awariami gazociągów.

W pracy przedstawiono skalę problemu eksploatacji instalacji gazowych, wskazując główne przyczyny ich awarii oraz pokazano wybrane zdarzenia spowodowane wybuchami gazu na świecie i w Polsce. Problem eksploatacji sieci gazowych wynika przede wszystkim ze znacznych długości rurociągów transportujących gaz ziemny co wiąże się ze wzrastającym zapotrzebowaniem na energię, wytwarzaną z wykorzystaniem gazu. Całkowita długość sieci gazowniczej cechuje się stałym wrostem. Tendencja ta jest podobna dla wszystkich analizowanych obszarów, tzn. w latach: od 1970 do 2000 wzrost długości był znacznie intensywniejszy niż obecnie. Ostatecznie w Polsce w roku 2013 długość sieci gazowych wynosiła 140 tys. km, w tym 20 tys. km sieci przesyłowej oraz 120 tys. km sieci rozdzielczej, a w Stanach Zjednoczonych 479 tys. km. Pokazano również strukturę sieci gazowych ze względu na średnice zewnętrzne rur stosowanych do budowy gazociągów, odpowienio: w Europie i USA. Około 20\% stanowią rury o średnicy poniżej 4" w Europie i 5" w USA. Także ok. 20\% całych zasobów stanowią rury o średnicach w zakresie od 4" do 10" w Europie oraz od 5" do 11" w USA. Przy czym w USA rury o średnicach z tego zakresu są najczęściej stosowane. W Europie najwięcej jest rur o średnicach od 10 " do 20 " czyli $28 \%$. Procentowy udział rur o średnicy powyżej 28 " dla Europy i 29 " dla USA jest podobny, a jest to odpowiednio 26\% i 28\%. Przyczyny awarii sieci gazowych można podzielić na następujące grupy: oddziaływania zewnętrzne, korozja, wady materiałowe i wady konstrukcyjne, ruch gruntu i inne oddziaływania środowiskowe. Do oddziaływań zewnętrznych zalicza się uszkodzenia podczas wykopów oraz inne uszkodzenia mechaniczne, wynikające z oddziaływań zewnętrznych, niezwiązanych z obsługą rurociągów gazowych, na przykład wandalizm i pożary. Wystąpienie tego typu uszkodzenia zależy od średnicy rur, grubości ścianki, głębokości ułożenia rur oraz - ogólnie - lokalizacji rurociągu (pod ziemią, nad ziemią lub w wodzie). Korozję rur można podzielić na zewnętrzną i wewnętrzną. Korozja zewnętrzna zależy od środowiska, w jakim znajdują się rury, natomiast korozja wewnętrzna zależy od możliwości występowania lokalnych nadciśnień, a więc od geometrii i ewentualnych niedokładności wykonania rurociągu oraz od składu chemicznego samego gazu i jego agresywności. Korozja postępuje wraz z wiekiem gazociągu i zależy od rodzaju materiału, z którego są wykonane rury, oraz grubości ich ścianki. Oddziaływania zewnętrzne oraz korozja są głównymi przyczynami większości awarii w Europie i Stanach Zjednoczonych.

Kolejna grupa pod względem powodowania awarii sieci gazowych, to wady materiałowe $\mathrm{i}$ wady konstrukcyjne, w tym połączeń spawanych. Zagrożenia powstania awarii z powodu wymienionych przyczyn wzrastają 
wraz z wiekiem gazociągu, ale zależą również od geometrii rurociągu i jakości wykonania. Z różnych powodów, np. pęknięcia rury, w instalacji może powstać chmura mieszanki gazu wybuchowego, która przemieszcza się w instalacji. Jeżeli napotka przeszkodę, to w rurach powstaje wysokie ciśnienie, które może doprowadzić do awarii instalacji zewnętrznej lub w przypadku instalacji wewnętrznej uszkodzenia budynku. Statystyki pokazują, że sieci gazowe z jednej strony przynoszą bardzo duże korzyści ekonomiczne, co powoduje rozwój tej branży gospodarki. Z drugiej strony, eksploatacja zewnętrznych $\mathrm{i}$ wewnętrznych sieci gazowych wiąże się z licznymi awariami $\mathrm{z}$ ofiarami $\mathrm{w}$ ludziach. Według statystyk prowadzonych od roku 1995 w Głównym Urzędzie Nadzoru Budowlanego w Polsce odnotowano 332 katastrofy budowlane spowodowane wybuchem gazu, 387 poszkodowanych, w tym 57 osób, które w ich wyniku poniosły śmierć oraz 330 rannych. Statystyki prowadzone przez Pipeline and Hazardous Materials Safety Administration (PHMSA) w Departamencie Transportu USA zarejestrowały w okresie ostatnich 20 lat 5664 zdarzenia, w których śmierć poniosło 347 osób, a 1348 osób zostało rannych. W Europie w grupie EGIG w okresie od 1970 do 2013 roku doszło do 1309 awarii sieci gazociągowej. Warto porównać liczbę awarii przypadających na $1000 \mathrm{~km}$ w wymienionych obszarach. Takie porównanie dla ostatnich dziesięciu lat w analizowanych obszarach pokazuje stagnację liczby wypadków. Mimo wielu regulacji prawnych ze względu na wiek instalacji nie da się uniknąć ich awarii. Z drugiej strony warto zauważyć, że liczba awarii w Polsce jest porównywalna z całą Europą, natomiast liczba wypadków w Stanach Zjednoczonych jest niemal trzykrotnie większa niż w Europie. To także może mieć związek z wiekiem instalacji, która, jest znacznie starsza niż w Europie. Z awariami sieci gazowych wiążą się ofiary w ludziach. Skutkami wycieków są niemal zawsze wybuchy, pożary i zawalenia budynków, które niemal zawsze dla ludzi kończą się tragicznie. Jak wynika z danych GUNB w Polsce liczba osób, które poniosły śmierć w latach 1995-2013 w wyniku katastrof budowlanych spowodowanych wybuchem gazu stanowi $14 \%$ wszystkich zmarłych w wyniku katastrof budowlanych, a liczba rannych, którzy ucierpieli w katastrofach budowlanych stanowi aż 39\%. Katastrofy spowodowane wybuchem gazu stanowią jedynie 5\% wszystkich katastrof, ale dowodem na ich niszczycielską siłę i tragiczne skutki jest wskazany niewspółmiernie wysoki odsetek rannych (39\%) i zabitych (14\%). Statystyki, które dotyczą Polski, mają nierównomierny rozkład. Liczba ofiar w stosunku do liczby wypadków jest duża, co powoduje, że przy mniejszej liczbie wypadków, każde wydarzenie o wielu ofiarach zaburza możliwość porównywania danych z poszczególnych lat. Mimo to można zauważyć, że w Polsce liczba ofiar wzrasta. W USA liczba ofiar ma tendencje do zmniejszania się, ale zdarzają się incydenty z dużą liczbą ofiar, tak jak w latach 2010 i 2014 . W USA też jest procentowo znacznie większy udział ofiar śmiertelnych wśród wszystkich poszkodowanych niż w Polsce. Oczywiście można też zauważyć, że całkowita liczba ofiar śmiertelnych w USA jest większa niż w Polsce. Jednak, gdy odniesiemy to do długości sieci, to niestety sytuacja w Polsce wygląda niekorzystnie. Podobnie jest w przypadku liczby rannych, przy czym tutaj liczba osób rannych przypadających na 100 tys. km w Polsce jest znacznie większa niż w USA. Występującą większą liczbę ofiar na 100 tys. km długości sieci gazowych w Polsce niż USA, przy jednocześnie znacznie większej liczbie awarii na $1000 \mathrm{~km}$ sieci można tłumaczyć zagęszczeniem ludności. Jak podaje GUS zagęszczenie ludności w Polsce w 2014 roku wynosiło 38,5 osób na km² a w Ameryce Północnej dwukrotnie mniej, bo 19,0/km². Inaczej mówiąc, długość linii przesyłowych jest związana z dużymi odległościami pomiędzy skupiskami ludzi i przez to wartości średnie liczby ofiar są mniejsze niż w Polsce.

Wzrastająca długość sieci, wzrost zapotrzebowania na energię oraz „starzejące” się zasoby sieci gazowych mogą doprowadzić do wzrostu liczby awarii, którym można zapobiec jedynie poprzez ich właściwą eksploatację i regulacje prawne a przede wszystkim ciągły monitoring. 